\title{
Technology of welding and repair works of hydropower plants units
}

\author{
M. Kakhovskyi ${ }^{1} \bullet$ Yu. Kakhovskyi ${ }^{1} \bullet$ A. Ievdokymenko ${ }^{1}$
}

Received: 3 September 2021 / Accepted: 25 October 2021

\begin{abstract}
In the course of long-term operation of hydroelectric units, they are subject to wear and tear, which negatively affects the power generating capacity of the hydroelectric power station. The existing repair technology provides the restoration of the geometric dimensions of the impeller chamber of the hydraulic unit using an austenitic cladding layer. However, this technology is characterized by the occurrence of cracks and delamination of the deposited layer during post-repair operation, which is negatively reflected in the production cycle of electricity. A new technology and welding consumables have been proposed for repair and restoration works of hydroelectric units at hydroelectric power plants, providing an increase in the quality level, high characteristics of hydroabrasive and cavitation resistance, and increasing of working period of hydroelectric power plants. Inspection of the body of the hydraulic unit was carried out, defects were identified and classified, the reasons for their occurrence were analyzed. The research results make possible to optimize the alloying system of the deposited metal, to determine the optimal welding mode, to reduce the amount of the martensite component and to develop new filler materials and the technology for welding and repair works of hydroelectric power plants.
\end{abstract}

Keywords: high-alloy weld metal; low carbon steel; transition zone; hydroelectric power station; cracks.

\section{Introduction}

A significant part of the world and Ukrainian electricity product by the hydropower industry. Hydroelectric units make the production of electricity in hydroelectric power plants. The principle of their operation work consists in the flow of water to the blades of a hydro turbine, which drives a hydro generator, which generates electricity.

The hydraulic unit consists of the water hydroturbine and the hydroelectric generator connected by a general shaft and located in the metal-concrete case of the impeller chamber (Fig. 1). The impeller chamber is a metal structure of low-alloy low-carbon steel (Steel 3).

The generating power of hydraulic units largely depends on the efficiency of the kinetic energy of water, which transmitted through the impeller chamber on the tur-

M.Yu. Kakhovskyi

m.kakhovskyi@gmail.com

${ }^{1}$ Paton Electric Welding Institute of NAS of Ukraine, Kyiv, Ukraine bine blade. In the process of long-term operation, the working surface of the cladding metal layer of impeller chamber is destroyed by cavitation and hydroabrasive wear.

For this reason, the gap between the impeller chamber and the turbine blades increases, the unproductive consumption of water kinetic energy also increases and the generating power of the hydraulic unit decreases.

To restore its generating capacity, welding and repair works of the metal cladding layer should be periodically made. Most surfacing as usual performed with electrodes TsL-11 type E-08Cr20Ni9Mn2Nb.

However, the use of this technology increasingly leads to the setting of hydraulic units for unscheduled repairs, due to the detection of cracks, spalling and delamination of the deposited cladding layer, which negatively reflected in the production cycle of electricity.

The purpose of this research was to determine and classify the types of defects formed during the impeller chamber exploitation, analyze the causes of their occurrence, as well as offer a new technology and welding consumables for repair.

Development of the technology of repair and restoration work of hydraulic units, which ensures an improve 


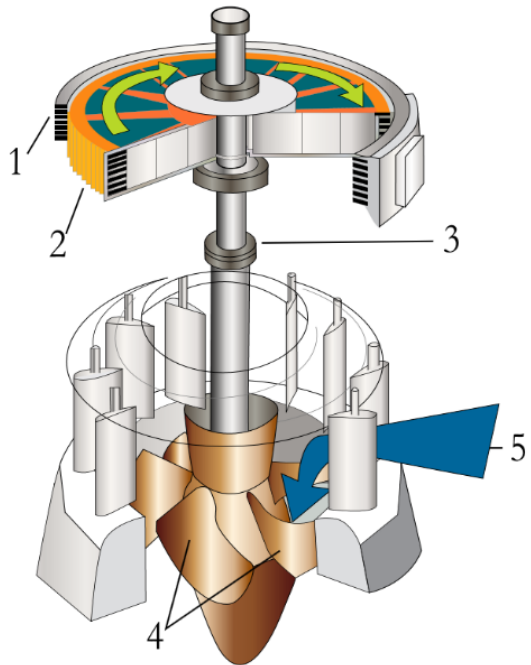

Fig. 1. Hydraulic turbine design: 1 - stator, $2-$ rotor, 3 - turbine generator shaft, 4 - turbine blades, 5 - water flow

ment of repair quality and decrease the formation of deposited metal delamination, an increase characteristics of hydroabrasive and cavitation resistance, and increase the duration of between-repairs term is an urgent task [1]

\section{Obtained Results}

The efficiency of welded joints of dissimilar steels is largely determined by the state of the metal in the transition zone. Structural and chemical heterogeneity, which, as a result of exposure to elevated temperatures and pressures, cyclic mechanical loads, thermal cycling and aggressive substances, undergoes degradation and initiates destruction by cracking, knife corrosion and metal delamination.

A timely assessment of the technical condition of the hydraulic unit and the identification of internal defects and damage is very important. Deterioration of the technical condition of the impeller chamber or its performance indicators should be timely detected during periodic inspections and regular technical surveys, as well as in emergency situations when violations are detected in the operation of the hydraulic turbine, carried out with a drained flow path.

In the course of these studies, an inspection of the impeller chamber was made, the service life of which at the time of inspection was more than 50 years. Due to the inaccessibility of inspection of the outer wall of the chamber, a visual inspection of the body was made only from the inside.

The results of the inspection showed that, based on the residual wall thickness, the chamber was made of sheet metal $26 . .28 \mathrm{~mm}$ thick in sheet-by-sheet assembly. Outside, the chamber is reinforced with stiffeners, which are pulled together and filled with cement mortar.

A cladding layer was deposited on the surface of the impeller chamber, which was made more than 20 years ago and was caused by significant corrosion of the chamber wall in the zone of movement of the impeller blades. Cladding was made in two stages: manual arc cladding of the base metal of the most corroded parts of the body to the required thickness, followed by cladding with a semiautomatic welding.

In addition, at the same time, injection of the solution into the resulting voids from the side of the contact of the chamber wall was made. The solution was pumped in the following way: in the zones of the detected voids on the inner side of the wall, the housing was drilled to the entire thickness of the wall in several places, after which the solution was supplied under low pressure (up to $1 \mathrm{~atm}$ ) and the moment of filling the void was recorded through the control hole. Then these holes were welded.

The previously mentioned features of the manufacture and subsequent repairs of the impeller chamber predetermined the main directions of searching for possible defects during its visual inspection, which can be reduced to the following:

- search for possible detachment of the cladding from the base metal of the case and the features of its damage;

- search for possible cracks in the cladding in the places of its application along the zones of joint joints of the segments of the shells of the chamber;

- inspection of zones in the places of transition of protective cladding to the base metal in order to identify possible acceleration of corrosion processes associated with heterogeneity of materials;

- search and analysis of places where repair welding of defects by manual welding was carried out in order to assess the possible acceleration of corrosion processes in the presence of residual stresses after welding;

- presence of pitting corrosion and intergranular cracking in the cladding and the depth of possible cavities;

- assessment of corrosive wear and depth of pits in the base metal and in cladding breakage points;

- assessment and consistency of ulcerative damage to the base metal of the impeller chamber;

The main results of visual inspection summarized as follows:

1. Each part of the chamber $(\varnothing \approx 8000 \mathrm{~mm})$ consists of 8 identical segments (segment length $\approx 3070 \mathrm{~mm}$ ), in the vertical joints of which narrow rectilinear gaps are observed, which indicates the absence of welding between them from the side of the inner surface of the chamber;

2 . The original cladding layer made by a $45^{\circ}$ angle. After that, a mechanical cleaning of the surfacing performed to ensure the required clearance between the housing wall and the blades. The overlay width is about $1600 \mathrm{~mm}$ and intersects the two lower shells;

3. At the time of inspection, about $50 \%$ of the cladding was exposed to significant pitting and pitting corrosion;

4. A significant number of local defects and breaks of the cladding layer noted, under which pitting corrosion of the base metal reaches more than half of the wall thickness. Cases of through corrosion observed in the places of such breaks;

5. In almost every segment of blade movement zone with cladding layer, the systematic cracks of various lengths are observed, mainly oriented at an angle of $45^{\circ}$. 
This fact indicates the exhaustion of the protective properties of the applied coating over the past period of operation;

6. Almost all types of corrosion damage, both of the base metal and the cladding itself (pitting corrosion and pitting corrosion with cracks) are observed in the places of vertical joints of the shell segments covered with cladding;

7. When tapping the surface of the chamber on the cladding, it was revealed that a significant number of voids are observed under it, which indicates not only its delamination from the base metal, but also significant corrosion processes occurring under it;

8. In the upper part of the chamber, at the transition boundary of the cladding layer, there is a band of intense pitting corrosion of the base metal to a depth of $15 . .20 \mathrm{~mm}$, with a width of up to $200 \mathrm{~mm}$. In the zone of repair welding with austenitic filler materials, significant corrosion is noted along the boundaries of the surfacing with a depth of up to $20 \mathrm{~mm}$, which indicates an increase in the rate of this process along the boundaries of dissimilar surfacing;

9. Significant corrosive wear of the weld beads made with UONI 13/45 electrodes without their subsequent overlap with austenitic filler materials. This type of welding in places where cladding is present almost completely damaged by corrosion, which indicates the need for their mandatory subsequent overlapping with austenitic type of deposited metal;

10. The performed repair protective austenitic surfacing in the lower part of the chamber at the border of the transition of the old cladding layer to the base metal characterized by significant pitting corrosion. This type of damage extends practically around the entire perimeter of the chamber. In most cases, corrosive wear is practically through, which requires the need for mandatory repair and restoration work in this area;

The results of inspection of the impeller chamber make possible to determine the types and nature of welding defects in the lining of the hydraulic unit. It should be noted that, according to the results of visual inspection, this protective casing of the impeller chamber of the hydraulic unit has practically exhausted its residual resource and requires major repairs or replacement.

In spite of the fact that the protective metal casing of the chamber is designed to prevent the washing out of concrete in the zone of intense water flow of motion of the blades, the problem of its tightness is a decisive factor.

The 50-year operation of this impeller chamber does not exclude the presence of significant corrosion in the places where the stiffeners are attached to the shell segments from the outside. This can lead to the separation of an entire segment and possible damage to the rotor blades.

The appearance of the corroded areas of the chamber, where it is necessary to carry out repair and restoration work, it is shown at Fig. 2-3.

For the more detailed study of the impeller chamber worn-out metal, some fragment cut out from the hydraulic unit. After that, the macrosections made from samples.

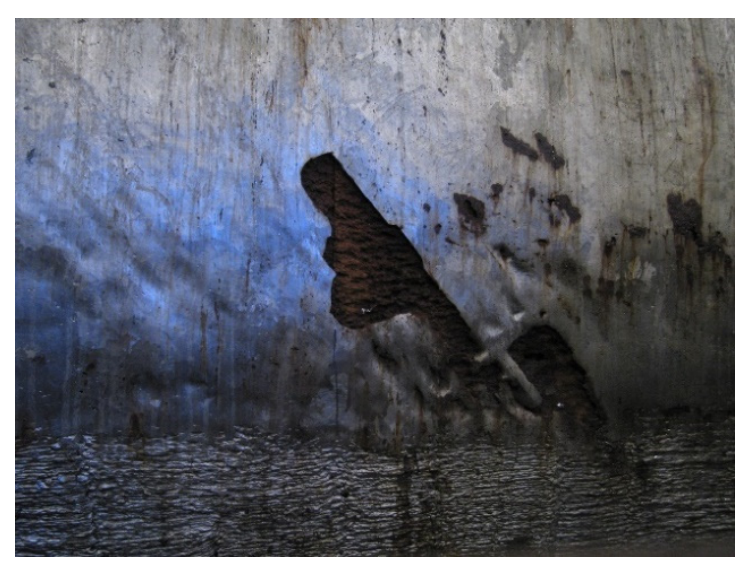

Fig. 2. Corrosion of the base metal and cladding layer

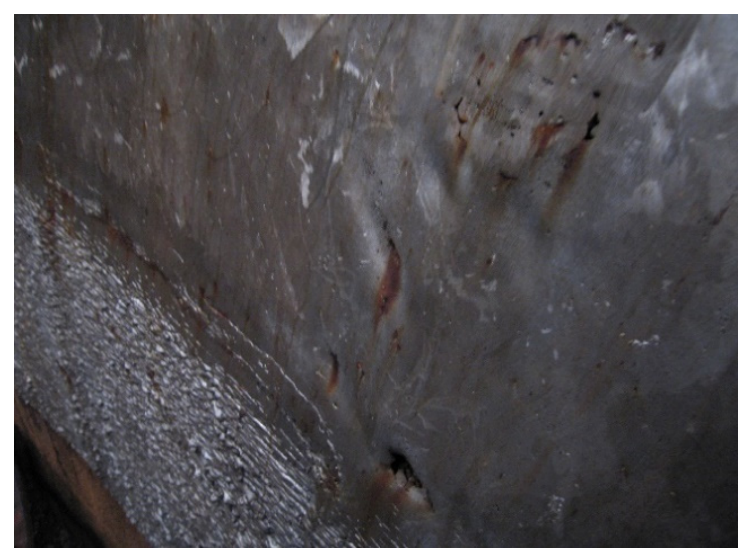

Fig. 3. Corrosion of deposited layer

The results of determining the chemical composition of the cladding and base metal layers (Table 1) showed that the top layer is the same as $08 \mathrm{Cr} 20 \mathrm{Ni} 9 \mathrm{Mn} 2 \mathrm{Nb}$ type, which confirms the fact that TsL-11 grade electrodes are used as the cladding layer.

Table 1. Chemical composition of the base and deposited metal of the samples.

\begin{tabular}{|c|c|c|c|c|c|c|}
\hline \multirow{2}{*}{ Sample name } & \multicolumn{6}{|c|}{ Mass fraction of elements, \% } \\
\cline { 2 - 7 } & $\mathrm{Cr}$ & $\mathrm{Ni}$ & $\mathrm{Mn}$ & $\mathrm{Si}$ & $\mathrm{C}$ & $\mathrm{Nb}$ \\
\hline Base metal & 0,05 & 0,04 & 0,50 & 0,18 & 0,16 & - \\
\hline $\begin{array}{c}\text { Deposited } \\
\text { metal, sample } \\
\text { no. 1 }\end{array}$ & 19,5 & 9,2 & 1,0 & 0,95 & 0,07 & 1,38 \\
\hline $\begin{array}{c}\text { Deposited } \\
\text { metal, sample } \\
\text { no. 2 }\end{array}$ & 19,0 & 9,0 & 1,0 & 0,90 & 0,08 & 1,35 \\
\hline
\end{tabular}

Studies of the manufactured samples showed, that the destruction of the layer deposited with coated TsL-11 
electrodes occurs through the formation of cracks, delamination and corrosion in it (Fig. 4), as well as cracks in the deposited metal along the grain boundaries (Fig. 5).
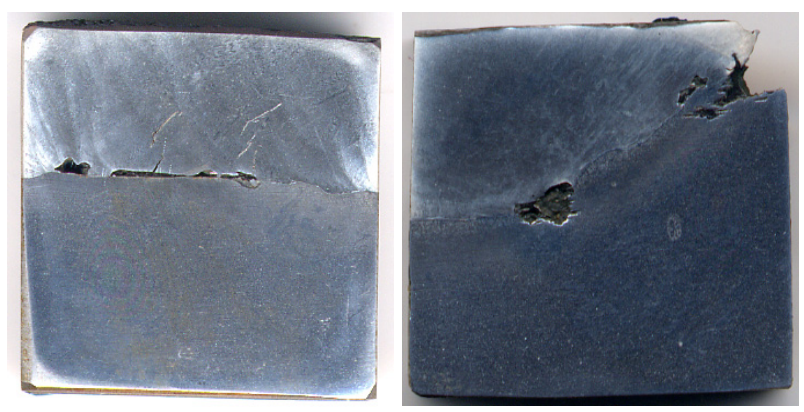

Fig. 4. Appearance of sample defects

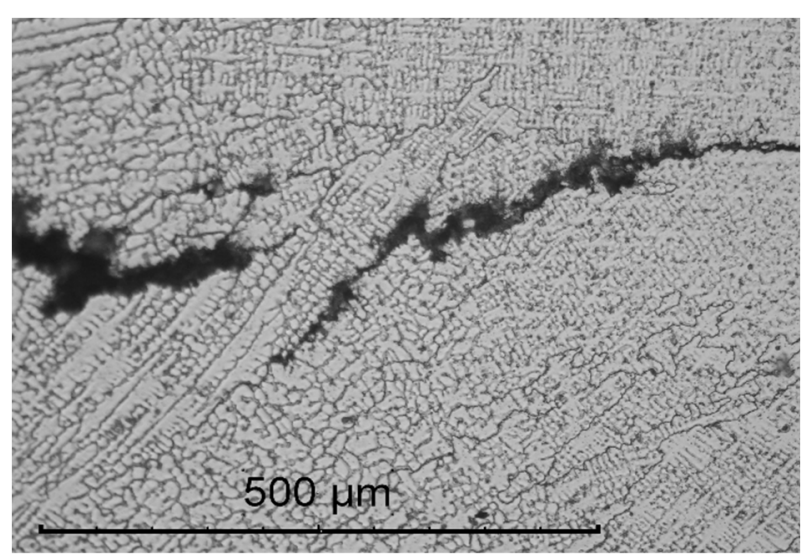

Fig. 5. Appearance of a crack in a weld metal along grain boundaries, $\mathrm{x} 200$

As shown by earlier studies [2, 3, 4], welding dissimilar joints from steels of different structural classes, pearlite with austenite, as a result of mixing of the filler and base metals at the fusion boundary crystallization layers of variable composition are formed, containing, 3...12 wt.\% Chromium and 2...8 wt.\% Nickel. Mostly, they have a martensitic structure, which reduces the performance of the welded joint due to the low ductility of the transition layer. The smaller its width, the weaker the adverse effect of this layer.

As a rule, under ordinary modes of manual and mechanized welding, the width of the transition layer in the fusion zone of dissimilar steels is $0.25 \ldots 0.5 \mathrm{~mm}$ $(250 \ldots 500 \mu \mathrm{m})$ [5]. Other sources indicate that the width of the transition layer is within $80 . . .115 \mu \mathrm{m}$ and $30 \ldots 140 \mu \mathrm{m}$ [6]. Welding pearlite metal with austenitic metal containing an increased amount of nickel $(20 \ldots 40 \%)$, the width of the transition layer is $85 \ldots 95 \mu \mathrm{m}$.

Previous studies have established, that the width of the transition zone in manual arc welding varies within $2 \ldots 135 \mu \mathrm{m}$ [7]. It is impossible to exclude the formation of a transition layer contributing to the formation of structural and chemical in homogeneities in the welded joint. How- ever, it is possible to reduce its adverse effect on the performance of the entire welded joint due to the rational choice of the weld metal alloying system, the proportion of the base and filler metal and by choosing the optimal welding mode.

Thus, we can conclude, that the destruction of the metal deposited with TsL-11 electrodes of the E-08Cr20Ni9Mn2Nb type on the working surface of the lining of the hydraulic unit impeller chamber made of Steel 3 is due to the formation of a martensite phase in the transition zone, initiating corrosion, cracking and peeling of the high-alloy layer.

In order to improve the quality and reduce the quantity of defects during repair, using the existing welding and repair technology for restoring the operability of the impeller chambers of hydraulic units, a new type of alloying of the deposited metal was selected, and new coated electrodes of the ANV-70BG type E-10Cr28Ni14Mn2 type were developed and manufactured.

New coated electrodes provide surfacing of corrosion and cavitation-resistant deposited metal layer on the working surfaces of the impeller chamber cladding made of Steel 3. The comparative tests of the deposited metal samples with the ANV-70BG and TsL-11 electrodes showed that the cavitation wear resistance of the deposited metal with the ANV-70BG electrodes is 2 times higher than the TsL-11 electrodes, and by the hydroabrasive wear resistance is $10 \%$ higher.

Analysis of the results obtained for the microhardness of the samples transition zone metal (Table 2) showed, that the values at $I=100 \ldots 110 \mathrm{~A}$ and $I=130 \ldots 140 \mathrm{~A}$ reach 1942...3600 MPa and 2380...3840 MPa respectively. The presence of martensite also confirmed by the results of $\mathrm{X}$-ray microanalysis of the content of alloying elements.

Table 2. Effect of welding current on the microhardness of the deposited metal with electrodes of the type E-10Cr28Ni14Mn2.

\begin{tabular}{|c|c|c|c|}
\hline \multirow{2}{*}{$\begin{array}{c}\text { Welding } \\
\text { current, A }\end{array}$} & $\begin{array}{c}|c| \\
\text { Transition } \\
\text { zone }\end{array}$ & $\begin{array}{c}\text { Middle of } \\
\text { surfacing }\end{array}$ & $\begin{array}{c}\text { Top of } \\
\text { surfacing }\end{array}$ \\
\cline { 2 - 4 } & $1595 \ldots 2580$ & $1688 \ldots 1780$ & $1875 \ldots 1940$ \\
\hline $80 \ldots 90$ & $1942 \ldots 3600$ & $1900 \ldots 2120$ & $1900 \ldots 2200$ \\
\hline $100 \ldots 110$ & $2380 \ldots 3840$ & $1971 \ldots 2080$ & $1800 \ldots 2080$ \\
\hline
\end{tabular}

This research studies have determined, that in order to minimize the risk of martensite formation in the transition zone and subsequent destruction of the deposited layer, it is necessary to limit the value of the welding current (no more than 90 A for electrodes type 
E-10Cr28Ni14Mn2 $\varnothing 3 \mathrm{~mm}$ ), which ensures the transition zone microhardness at the $1595 \ldots 2580 \mathrm{MPa}$ level.

The developed technology of manual arc welding using ANV-70BG electrodes type E-10Cr28Ni14Mn2 provides an improvement in the quality of repair surfacing of hydraulic units, in comparison with TsL-11 electrodes by reducing the quantity delamination and defects of the deposited metal, increasing its characteristics of hydroabrasive and cavitation resistance, and increasing between-repairs term.

\section{Conclusions}

1. The absence of a cladding layer in worn-out areas restored with UONI 13/45 electrodes leads to the formation of significant corrosion and indicates the need for manda- tory subsequent overlapping with austenitic type of deposited metal;

2. Due to the mixing of the pearlite (base) metal with the austenitic (TsL-11), a chemical heterogeneity is formed with a reduced content of chromium and nickel, which leads to the formation of brittle martensite interlayers, which initiates the formation of cracking;

3. An increase in the value of the welding current during surfacing with ANV-70BG electrodes above $90 \mathrm{~A}$ enhances the structural and chemical heterogeneity of the transition zone metal and reduces its corrosion resistance;

4. The cavitation wear resistance of the deposited metal with the ANV-70BG electrodes is 2 times higher than that of the TsL-11 electrodes. At the same time, hydroabrasive resistance is $10 \%$ higher.

\title{
References
}

[1] Y. Kakhovskyi, M. Kakhovskyi, A. Ievdokymenko, "Actuality of development of welding and repair technology for the hydroenergy industry equipment", Materiali XIII Mizhnarodnö̈ naukovo-tekhnichnoï konferentsii "Novi materiali i tekhnologiï v mashinobuduvanni-2021". Kyiv, 2021, pp. 10-11.

[2] K.A. Yushchenko, et al., "New electrodes for repair surfac-ing of damaged lining of impeller chamber of HES hydropower units", The Paton Welding Journal, No. 5-6, pp. 90-92, 2015. https://doi.org/10.15407/tpwj2015.06.20

[3] M.Yu. Kakhovs'kii, "Pokriti elektrodi dlya ruchnogo dugovogo zvaryuvannya riznoridnikh stalei”, Materiali VIII mizhnarodnoi konferentsiï molodikh uchenikh ta spetsialistiv, “Zvaryuvannya ta sporidneni tekhnologiï”, Vorzel', 2015, p. 52.

[4] Y. Kakhovskyi, M. Kakhovskyi, A. Ievdokymenko, "Analysis of the causes of defects formed during repair and restoration of hydropower units", Materials of the International conference "Innovative technology and engineering in welding and allied processes PolyWeld - 2021”. Kyiv, 2021, pp. 9-10.

[5] Yu.N. Gotal'skii, Svarka raznorodnykh stalei, Kyiv, Ukraine: Tekhnika, 1981.

[6] V.N. Zemzin, Svarnye soedineniya raznorodnykh stalei, Moskow, Russia: Mashinostroenie, 1966.

[7] K.A. Yushchenko et al., "Investigation of transition zone of low-carbon steel joint with high-alloyed Cr-Ni deposited metal", The Paton Welding Journal, No. 6-7, pp. 143-146, 2014. https://doi.org/10.15407/tpwj2014.06.31

\section{Технология сварочно-ремонтных работ объектов гидроэлектростанций}

\author{
Н.Ю. Каховский, Ю.Н. Каховский, А.С. Евдокименко
}

Аннотация. В ходе длительной эксплуатации гидроагрегатов, они поддаются износу, что негативно сказывается на энергогенерирующей мощности ГЭС. Существвющая технология ремонта обеспечивает восстановление геометрических размеров камеры рабочего колеса гидроагрегата с помощью аустенитного плакирующего слоя. Однако данная технология характеризуется возникновением в ходе послеремонтной эксплуатации трещин, отколов и отслоений наплавленного металла, что негативно отображсается на производственном иикле электроэнергии. Предложена новая технология и сварочные материалы для проведения ремонтно-восстановительных работ гидроагрегатов ГЭС, обеспечивающая повышение уровня качества, высоких характеристик гидроабразивной и кавитационной стойкости, и как следствие, повышенного межремонтного срока. В роботе проведен осмотр КРК поставленного на ремонт, определены и классифицированы образующцеся дефекты, проведен анализ причин их возникновения. Результаты исследований позволили оптимизировать систему легирования наплавленного металла, определить оптимальный режим сварки обеспечивающий снижение количества мартенситной составляющей и, как следствие, разработать новые присадочные материаль и технологию сварочно-ремонтных работ объектов гидроэлектростанций.

Ключевые слова: высоколегированный наплавленный металл; низкоуглеродистая сталь; переходная зона; гидроэлектростанция; трещиныл. 


\section{Технологія зварювально-ремонтних робіт об’сктів гідроелектростанцій}

\section{М.Ю. Каховський, Ю.М. Каховський, А.С. Євдокименко}

Анотація. В ході тривалої експлуатації гідроагрегатів, вони піддаються зносу, щуо негативно позначається на енергогенеруючої потужності ГЕС. Існуюча технологія ремонту забезпечує відновлення геометричних розмірів камери робочого колеса гідроагрегату за допомогою аустенітного плакуючого шару. Однак дана технологія характеризується утворенням в ход $i$ післяремонтної експлуатаџії тріщин, відколів і відмарувань наплавленого металу, щьо негативно відображається на виробничому циклі електроенергії. Запропоновано нову технологію і зварювальні матеріали для проведення ремонтно-відновлювальних робіт гідроагрегатів ГЕС, що забезпечує підвищення рівня якості, високих характеристик гідроабразивної і кавитаиионної стійкості, $і$ як наслідок, підвищеного міжремонтного строку. В роботі проведено огляд КРК поставленого на ремонт, визначено та класифіковано дефекти, проведено аналіз причин їх виникнення. Результати досліджень дозволили оптимізувати систему легування наплавленого металу, визначити оптимальний режим зварювання забезпечити зниження кількості мартенситної складової $і$, як наслідок, розробити нові присадкові матеріали і технологію зварювально-ремонтних робіт об'єктів гідроелектростаниій.

Ключові слова: високолегований наплавлений метал; маловуглецева сталь; перехідна зона; гідроелектростаниія; тріщини. 